\title{
The Emergence of a Muslim Minority in the Ado-Ekiti Kingdom of Southwestern Nigeria
}

\author{
Sulaiman Kamal-deen Olawale
}

\begin{abstract}
This paper seeks to provide a sociological reinterpretation of Islam's presence in the Ado-Ekiti kingdom by unraveling the various essentially sociopolitical and economic factors that, along with religious factors, account for its emergence and growth. I have adopted a historical methodology (narrative) to understand and explain its appearance, functions, and contributions in the kingdom. This will be supplemented with material found in public and private libraries, archives and museums, and artifacts.

The paper reveals that the exact date of Islam's introduction remains unknown and that local Muslims worshipped in secret until 1836, when a Muslim named Ali Atewogboye ascended the throne. He and his successor gave Islam a strong foundation due to their sociopolitical and economic motivations. The paper closes with an account of the factors that facilitated Islam's spread, the problems faced by local Muslims, and how they have tried to resolve these problems.
\end{abstract}

\section{Introduction}

Arab traders who came via the trans-Sahara trade routes introduced Islam into West Africa around the tenth century. During the next century, it entered the lands of modern-day Nigeria, especially the Borno Empire, when the Kanem ruler Umme Jilm (r. 1085-97) converted. ${ }^{1}$

Sulaiman Kamal-deen Olawale, Ph.D., is a lecturer in the Department of Religious Studies, Ekiti-State University, Ado-Ekiti, Nigeria. 
Scholars are uncertain when Islam actually penetrated Yorubaland. Nigerian Muslim scholar Shaykh Adam (d. 1992)² opines that Islam came from Mali during the first half of the fourteenth century; others believe that the Wangarawa, Muslim traders from contemporary Mali, arrived in the region during the fifteenth century. ${ }^{3}$ According to Gbadamosi, however, this penetration probably occurred during the seventeenth century and the Yoruba were both receivers and propagators of Islam before the end of that century. ${ }^{4} \mathrm{By}$ the beginning of the nineteenth century, Islam had become firmly rooted as far as the coast.

Scholars also disagree over where Islam was introduced into Yorubaland. Adam maintains that since Islam entered via the activities of Mali traders, the Yorubas refer to it as the religion of the Mali people. ${ }^{5}$ Colloquially it eventually became known as Esin Mali (Malian Religion) and dialectically as Esin Imale. Another source claims that Islam was called Esin Imale because its tenets were too hard for the Yorubas of that time to understand. ${ }^{6}$ By the seventeenth century, mention was made of Muslims in Yorubaland, contrary to Samuel Johnson's assertion that Islam was introduced there only at the close of the eighteenth century. ${ }^{7}$ But regardless of where it was introduced, Muslims were living there by the first half of the seventeenth century. Some were teachers; others were merchants and slaves from Hausaland, Borno, and the far north.

Given Islam's presence during the seventeenth century and the existence of trade between North Africa and Yorubaland (including Ekiti), it can be suggested that Islam must have reached Ekiti before the eighteenth century - perhaps as early as the seventeenth century - for Otun-Ekiti had been a renowned commercial center since at least $1578 .{ }^{8}$ This could be further strengthened by the fact that such Ekiti products as kolanuts were items of trade were found as far afield as North Africa before the nineteenth century. ${ }^{9}$

However, it is beyond debate that Islam had spread to many parts of Yorubaland by the eighteenth century. In fact, before the end of this century the Yoruba were as much receivers as they were preachers of Islam. For instance, by 1856 the timi (king) of Ede was a Muslim, and by 1836 the ewi (king) of Ado-Ekiti was a Muslim: King Ali Atewogboye (1836-86). Ibadan, Iwo, Iseyin, Ede, and New Oyo were commonly regarded as Muslim areas. By 1878 Oyo had at least twelve mosques. Due to the establishment of several Qur'anic schools, Ibadan later emerged a center of Islamic learning. ${ }^{10}$

The actual date of Islam's introduction into Ekitiland also cannot be given with any precision. As with many other parts of Yorubaland, its advent was unannounced and unplanned. The first Muslim inhabitants worshipped privately and in secret for many years, for they were afraid of being persecuted, 
molested, or even killed due to their relatively small numbers. They only began to practice their faith openly as their numbers increased. In Ekiti, Islam is said to be as old as Ekitiland itself. The truth of this can be seen in a Yoruba saying:

We met the Ifa oracle in the world.

We met the religion of Islam in the world.

Christianity came in the peak of the noon. ${ }^{11}$

The general view is that Islam penetrated Ekiti during the Yoruba intertribal wars (1840-93) $)^{12}$ due to those of its people who were captured, sold and, after the wars ended, returned home as converts. Gbadamosi attributes Islam's late arrival in Ekitiland and other eastern parts of Yorubaland (i.e., Ilesha, Ondo, and Okitipupa) to the region's traditionally very limited contact with the Muslim centers to the west and the north. ${ }^{13} \mathrm{He}$ further claimed that the religion's rapid spread and growth in Ekitiland and other eastern parts of Yorubaland actually started toward the end of the nineteenth century, when many formerly captured and sold Yorubas in the diaspora started to return as free men and women. Many of them had become Muslim in Epe, Ilorin, Iwo, Ibadan, and elsewhere. Once back home, they contributed greatly to Islam's spread and sometimes actually introduced it to their neighbors. One example of a formerly enslaved Muslim returnee who contributed greatly to establishing Islam in Ekitiland and its environs was Amodu Adewumi Agunsoye, who later became King Ewi of Ado-Ekiti (r. 1910-37). ${ }^{14}$

Another view is that Islam had been in Ekiti before these captives and former slaves returned. For instance, Agbetola ${ }^{15}$ maintains that Islam spread to Ekiti during the eighteenth century on the grounds that it was introduced into Ido-Faboro Ekiti during the reign of King Olojudo Okeoro (r. 1835-95). He asserts that by 1836, Ekiti had had a Muslim ruler at Ado-Ekiti: King Ali Atewogboye. But Ajibade ${ }^{16}$ opines that the king had accepted Islam before his ascension. Kareem, ${ }^{17}$ who supports this view, says that Atewogboye's acceptance of Islam before his ascension indicates that Islam had been known there during the reign of his predecessor, King Ewi Owaroloye (r. 1808-36) or even earlier. These seemingly contradictory views can be reconciled if we bear in mind that Islam's spread in Ekitiland did not follow the same pattern or take place at the same time.

\section{The Spread of Islam in the Ado-Ekiti Kingdom}

Islam began entering Ado-Ekiti during the reign of Oba Ewi Owaroloye, due to efforts of Ado-Ekiti traders in Oshogbo, Oyo, and Ilorin as well as 
some freed slave returnees. Although there was just a handful of Muslims at that time, fear of intimidation and persecution from their fellow villagers was rampant. ${ }^{18}$ But as fate would have it, Prince Ali Atewogboye was a convert. No one knows how or why he had embraced Islam, but Agbetola ${ }^{19}$ and Ajibade ${ }^{20}$ both assert that he ascended the throne as a Muslim. They further claim that since he was a hunter, he might have converted during a hunting expedition to neighboring villages. The fact that he was a Muslim greatly enhanced Islam's establishment in Ado-Ekiti, Ekitiland, and its environs. Ajise $^{21}$ added that Islam was firmly established in Ekiti during his reign and that its practice was highly encouraged.

The above evidence shows that the king was a Muslim before he became ewi of Ado-Ekiti in 1836, for he grasped the opportunity to give Islam a good foundation. At this time the isolated Muslims started finding the courage to openly identify themselves with Islam. Their ordeal, however, worsened after Ibadan invaded the region. Despite their increased membership, they were beset with severe and deadly opposition following Atewogboye's death in $1886,{ }^{22}$ because the people of Ado-Ekiti at that time were primarily followers of the traditional religion. The now-Muslim ex-slaves who returned home were entirely different in their orientation, ${ }^{23}$ which created a lot of problems for them. For instance, the traditional police harassed them: they could not move around freely around the town; were forbidden to wear turbans (held to be exclusive for a special king's masquerade (a symbolic representative of ancestors in Africa) called ede that had the right to wear "lions" round the head); were threatened with charms, demons, and masquerades, as well as whippings (sometimes actual) to make them return to their former faith. The persecution was so tense that Muslims once again had to pray in secret and not call the adhān for fear of being attacked. In fact, when the unabated persecution became unbearable, they decided to migrate with their families and belongings. ${ }^{24}$ They then started their great trek, which eventually led them to Oke-Ilawe in Iyin-Ekiti, where they settled. Their emigration was similar to the Prophet's migration to Madinah with many of his Companions.

The ascension to the throne of King Ewi Amodu Adewumi Agunsoye 1 of Ado-Ekiti in 1910 brought relief to the Muslims. The king, an ex-slave who had served in Iwo, Osun State under the reign of King Oluwo of Iwo Momodu Lamuye (r. 1860-1906), ${ }^{25}$ returned home in 1908. On his ascension, he immediately ordered the Muslims who had relocated to Oke-Ilawe to return home and also ordered the efa (the traditional police) to stop persecuting Muslims. He guaranteed the Muslim's free movement and legalized the wearing of turbans. 
As a result, Islam began spreading during and after his reign. When many people, among them Bello of Ebiri, Ategbe, Fawaye of Irona, Ibrahim Orikogbodo, became Muslim, Islam in Ado-Ekiti witnessed a great turning point: A piece of land near Odo-Otu, where the present Ado-Ekiti central mosque is situated, was donated King Agunsoye for a purpose-built mosque as a symbol of official acceptance. ${ }^{26}$

From the reign of King Agunsoye onward, Muslims faced little or no persecution from the traditionalists and thus were able to establish a foothold in Ado-Ekiti. Islam was also spread by the freed slaves of Ado-Ekiti origin who had embraced Islam while in the diaspora. Upon their return home, they joined forces with other local Muslims. Prominent among these freed slaves were Bello Awolusi Kolorogun, the first Chief Otun Muslim of Ado-Ekiti for quite a long period, who had already embraced Islam. He practiced the doctrine alone, without support from anyone, for seven consecutive years and thereby earned the nickname Kolorogun (one who has no rival). ${ }^{27}$ Also, Ali Olokodana and Bello Egunjobi, both of whom had been slaves in Lagos, were from Ogbon-Ado and Okesha, respectively.

\section{Factors behind Islam's Spread}

Despite the problems that faced Islam in Ado-Ekiti, it nevertheless forged ahead due various factors.

War. The Yoruba people are a combination of separate ethnic groups, among them the Egba, Ife, Ijebu, Owu, Ilesha, and Ekiti. Like any other community, the Yorubas have engaged in fraternal strife that has resulted in population displacements. ${ }^{28}$ Tribal wars started in earnest during the reign of one Alaafin of Oyo, Aole Arogangan, a time when the Oyo Empire's decline began. According to Johnson, during the reign of Aole the empire's cup of iniquity was full: cruelty, usurpation, and treachery were rife, especially in the capital. The provinces frequently groaned under the yoke of oppression. Confiscation and slavery for the slightest offence became matters of daily occurrence, and tyranny, extortion, and lawlessness on the part of the royal family members went unchecked. ${ }^{29}$

When Aole died, the enmity that he had created through his tyrannical rule caused the Yorubas to throw themselves into a series of wars. Eventually the Fulani seized power in Ilorin. Abdusalami, the Fulani emir, faced no rivals from the Yoruba kings or chiefs because he had subjugated Onikoyi, shattered the Kakanfo's (Afonja's) army, and killed Solagberu. This made him resolve to conquer all of Yorubaland and place himself on the throne. ${ }^{30}$ 
Having destroyed the Oyo Empire, its ethnic groups (e.g., the Ife, Egba, Ilesha, Ijebu, and Ekiti, to mention a few) sought to establish their own independent kingdoms. The ensuing Owu war led to the capture and enslavement of many Yorubas and, ironically, to a great number of conversions among them. For example, after Ilorin subjugated Ago-Oja (present-day Oyo Town), the latter became its tributary and its people adopted Islam.

Elebu succeeded his brother as the bale (leader) of Ago. As might be expected, he was not on good terms with Atiba; but the latter had already risen to such height of greatness and popularity that Elebu could neither crush nor turn him out of the town. Thus they remained antagonists until Elebu was drowned in the river during Gbodo war. Before Elebu's death, Anajaku of Ilorin, to whom Ago-Oja paid tribute, summoned them both to Ilorin and asked Shitta (his sovereign), to effect reconciliation between them. The turban was given to both of them as a sign of brotherhood in the Muslim faith. This reconciliation was only on the surface, and thus by no means real. It was at this time that all children born at Ago received Muslim names and many adults and aged people changed theirs in order to be in good favor with the people of Ilorin, who then infested the country. ${ }^{31}$

Also around this time Ilorin placed a contingent of soldiers at the service of the Ado-Ekiti, which was fighting Ibadan during the Jalumi war. This war, as the others had done, caused the enslavement and subsequent removal of many Yorubas. It should be noted that in all of the wars referred to, none was used as a means of forcible conversion to Islam; rather, they were purely political. Part of the Yoruba wars extended to Ado-Ekiti, which had also been exposed to attacks by other powerful kingdoms and raiders, such as the Benin and Nupe kingdoms. ${ }^{32}$

Economic activities. These activities consisted of farming, hunting, weaving, and trade. Trade seems to have been the usual means of introducing and spreading Islam in Ekiti. Along with functioning as a vehicle through which ideas and other people's culture infiltrated different areas, the frequency of the ensuing social interaction facilitated economic activities between towns and villages and helped maintain a considerable degree of cultural homogeneity. This situation assisted the diffusion of new ideas and lifestyles - among them Islam - in Ado-Ekiti. For instance, prior to the Kiriji war (1878-86) ${ }^{33}$ during the reign of King Ali Atewogboye, some non-native Muslims from Epe (Lagos State) and Ilorin (Kwara State) were living in Ado-Ekiti town. These traders in textile and other materials ${ }^{34}$ were guests of the king, who later would take them around to the houses of the town's important chiefs and personalities so they could sell their wares to them. 
At the early stage, Muslims faced some persecution at the hands of the followers of the traditional religion, especially at the hands of the masqueraders, when the latter discovered that the former were converting important personalities in their midst to Islam. ${ }^{35}$

From the foregoing, one can conclude that, to a certain extent, Islam spread to Ado-Ekiti through the efforts of itinerant Muslim traders. But it was established by the first Muslim converts with the support of ex-slaves who had returned to their birthplaces to encourage people to join the religion.

Sufism. Sufism, an important branch of Islam, ${ }^{36}$ is founded upon sincerity, in both conduct and intention. Its ultimate goal is communion with Allah and the attainment of His pleasure. Its followers are mystics or spiritualists who adhere to a specific lifestyle. Their successful missionary work helped propagate Islam in many parts of Ekiti. In addition, they made the people more devoted to Islam through the efficacy of their prayers, which were able to solve some personal problems among Ekiti's Muslims. Over time, their litany spread to most of the mosques and today one can scarcely find a Muslim gathering at which al-șalät al-fätihah is not recited. Many of Ekiti's Muslims congregate in their zāwiyah for the wazifáh (a word of mysticism) and the hailala (the shahädah) to develop the spiritual being of the murìd.

The presence of non-locals. Many non-locals contributed immensely to Islam's spread and growth in Ado-Ekiti. Apart from such early itinerant Muslim traders and scholars as Alhaji Najimudeen, an Islamic preacher from Ibadan who helped produce many Islamic scholars in Ado-Ekiti, the contributions of other people like the late Chief M. K. O. Abiola from Abeokuta (Ogun State), who used his money to propagate Islam throughout Nigeria, and particularly in Ekiti, must be mentioned. He was responsible for, among other things, building the first mosque in the University of Ado-Ekiti and the central mosque in 1991. In the same town, Alhaji Ibiyemi contributed to the teaching of Arabic and Islamic studies and also established an Islamic elementary school (named Ola-Oluwa) and many primary schools. ${ }^{37}$ Alhaji Sulaiman Akinbami of Ibadan has been contributing to the development of Islam in Ekiti in a similar way to that of Abiola, among them sponsoring television and radio programs in Ado-Ekiti.

Many other non-Ekitis continue to make important contributions in this regard. For instance, M. A. Abdu-Raheem of Ibadan has helped produce scholars of Arabic and Islamic studies from Arabic schools in Ekiti and in the University of Ado-Ekiti. 
Internal factors. Islam, as remarked earlier, played a very significant role in the life of Ado-Ekiti's people. The early converts, although few, were very dedicated and steadfast even in the face of persecution. This sustained Islam's spread in the area. Another factor was the contribution of former slaves who had converted. For instance, one of them became the town's first Muslim king, who hosted Oyo Muslim settlers from Oyo Alaafin and Ibadan during his reign. He also invited Muslim clerics to his realm to help him pray for the town's peace and progress. Among these clerics was Alfa Ibrahim, who started an open-air preaching, led them in prayer, and taught them the rudiments of Islam. ${ }^{38}$

Also, the ascension of another Muslim king, Ewi Amodu Adewumi Agunsoye (1910-37), helped the Muslim returnees settle down peacefully. The king encouraged them to unite and practice Islam openly. ${ }^{39}$ More importantly, he ordered the efas (the traditional police) and the traditional worshippers to stop persecuting the Muslims. Thanks to this official protection, Muslims continued to make appreciable progress during and after his reign. Many of their fellow citizens embraced Islam, as did a member of the efa, among them Buremo Orikogo. This was a significant turning point. The king also donated the land upon which the present Ado-Ekiti central mosque was built. ${ }^{40}$ This was a great improvement upon observing the obligatory five daily prayers in an open-air mosque. Since then, Muslims have no longer faced serious persecution from the traditional worshippers and have established their presence both in the town and in other parts of Ekiti. Furthermore, the early Muslim scholars established some Qur'anic schools, which also helped the religion spread.

Islam is also full of social activities, such as those that accompany the naming of a child, walimah, marriage ceremonies, festivals (e.g., the Prophet's birthday), and Eid al-Adha, all of which attracted the interest of the nonMuslims. Non-Muslim relatives were invited to attend and participate in these ceremonies and festivals, all of which were celebrated with pomp and pageantry. In addition, Islam has some customs that resemble indigenous ones: polygamy, the sacrifice of animals during festivals, and full regard for traditional authorities. Christianity preached against all of these, which caused some people to praise and embrace Islam. ${ }^{41}$ Another aspect that attracted many traditionalists were zakat and șadaqah. Some people considered these to be acts of generosity on Islam's part, and thus preferred it over those religions that did not cater to the needs of others, especially the poor and the needy.

Another major factor was Islam's ability to solve personal or community problems. Among the early propagators of Islam, the alfas acted as mendicants 
and preachers. Sometimes they claimed to have the ability to make preparations that could solve certain personal problems. For example, barrenness among women, increased sales, preventing robbers from entering one's domicile, or rendering gunshots harmless. All of these attracted the attention of non-Muslims. Some alfas also made drugs that were held to cure headaches, abdominal pains, smallpox, and other ailments. Some categorically asserted that they could foretell the future by manipulating numbers ( $h i s a \bar{a} b$ ) or making marks in sand placed on a tray $(\mathrm{khatm})$. Although Islam condemns such practices, some traditionalists were interested because they conformed to traditional practices of consultancy (e.g., opele or ifa) to foretell future events. Invariably some adherents of traditional religions were highly fascinated with such powers and so opted for Islam. ${ }^{42}$

Also, many preachers' eloquent preaching and oratory prowess convinced some people to accept Islam. During the early years, preachers usually preached at night accompanied by hurricane lamps and sometimes conducted open-air $d a$ 'wah. It should be noted, however, that many early converts in Ado-Ekiti did not really understand what they were to do from the Islamic point of view. This explains why many of them became syncretists.

The hajj was - and remains - an attractive factor. From the earliest years of Islamic history and even now, those who complete the pilgrimage are accorded special privileges and held in high esteem by their peers. They even receive a title upon their return home: alhaji for men and alhaja for women. Probably because of the prestige enjoyed by this class of people and because of the cheap products available at Makkah, some non-Muslims have gone there and posed as Muslims. Whatever may be the case, the elaborate sending-off parties as well as the welcome-home celebrations, together with the accompanying pomp and pageantry, have motivated some non-Muslims to embrace Islam. In addition, the contributions of the Atoyobos (returnees from Oyo) in spreading Islam in Ado-Ekiti were enormous. As soon as they arrived, they started calling people to Islam and made a large number of converts. ${ }^{43}$

Impressive celebrations of such festivals such as Eid al-Fitr, Eid al-Kabir, Mawlid al-Nabi, and Laylat-al-Qadr, to which non-Muslims are invited, also considerably enhance Islam's continued expansion. Such meals were usually accompanied by the drinking of palm wine, which violates Islamic teachings but was used to entice the people to the religion. On these occasions, Muslim converts would enlighten their relations about the religion. ${ }^{44}$ In addition, Muslims encourage intermarriage with non-Muslims so that those non-Muslim men who want to marry Muslim women will convert. 
The deeply rooted spirit of communal unity in Islam brought about a visible unity that, in turn, served as an avenue for preaching. Muslims had good relationships among themselves, as opposed to the isolationist behavior of the traditionalists. In addition, they loved one another, believed that they belonged to one large family, and showed love to non-Muslim neighbors - an attitude that attracted the traditionalists. In contrast to them, the Muslims did not kill each other, had no misunderstandings with each other, shared what they had, and helped each other. All of these exemplary behaviors endeared Islam to the non-Muslims, who gradually accepted the religion. ${ }^{45}$

To crown the manifestation of communal unity, the early Muslims used chieftaincy titles as a tool to consolidate Islam, for the people loved titles. Thus they created some religious "titles" for the converts and conferred them upon some traditional chiefs who hesitated to embrace Islam out of fear that they would lose their traditional chieftaincy titles.

Also, Christian indoctrination of Muslim children attending missionary schools and the discrimination experienced by some of them compelled some Muslim communities in Ado-Ekiti to consider the establishment of their own schools as imperative. ${ }^{46}$ The best way to achieve this was to form themselves into united organizations. The first such organization to emerge was the AnsarUd-Deen Society of Nigeria, which sprang up at the turn of the twentieth century and encouraged Muslim students to acquire a western education without losing their religious identity. The Muslims, firm in their desire to have Islamic schools and colleges through the assistance of the society, which they believed was duly registered and in a better position to negotiate with the government, urged their members to combine their resources to award scholarships to deserving Muslim students. They believed that this would enhance Islam's prestige in Ado-Ekiti. The organization was established in Lagos in $1923^{47}$ and appeared in Ado-Ekiti in 1945. ${ }^{48}$

\section{The Challenges Facing Islam and Muslims in Ekiti State}

Disunity. The Muslims Ado-Ekiti face intra-societal discrimination. For example, some of the imams see themselves as rivals rather than as integral partners. ${ }^{49}$ Struggling for societal supremacy, the ensuing power struggles over mosques and elsewhere are defeating the ideal of a unified purpose. Rather than working together as a common force against their common "enemies," they engage in clandestine fights while posing as friendly people. In a nutshell, the main issue now is who represents the community to the government. 
The low level of education. Literacy in the English language contributes immensely to the relevance of the individual and his/her location in Nigeria's social hierarchy. It is, however, disheartening to note that a significant number of the people in Ado-Ekiti who have no western education are Muslim. ${ }^{50}$ As many of those who have white-collar jobs are non-Muslims, a very large number of people found in the blue- and pink-collar jobs are Muslim. This is noticeable in the various marketplaces and motor parks, where the majority of petty traders, hawkers, and commercial drivers are Muslim.

Poverty. Islam in Ado-Ekiti lacks financial patronage. As the majority of Muslims live far below the poverty level, the few of them who are well-to-do are always requested to donate money to sponsor an Islamic program. ${ }^{51}$ Their wealth, however, obviously cannot pay for everything. The community's overall poverty can be seen in the low level of development found in the various mosques, few of which can boast of a standard ablution pool, toilet facilities, a good water supply, and adequate space for worship and parking cars. Every project is sponsored through contributions from petty traders, peasant farmers, and poor artisans - the majority of the Muslims. ${ }^{52}$

Islamic programs are mostly heard on radio and television only during Ramadan, when Muslims all over the kingdom are required to pay a certain amount of money to sponsor them. At the end of each Ramadan, a huge amount of money is always owed to media houses for these sponsored programs.

Political weakness. Muslims in Ado-Ekiti might be a minority group, ${ }^{53}$ but they are politically significant. Although they participate overwhelmingly in electoral activities, as well as vote and contest elections, their low numerical strength puts them at a disadvantage. As a result, they are always treated as second-class citizens. Some Muslim political office holders serve mainly in deputy capacities. In short, they have not been adequately represented in the government, a fact that affects the growth of Islam.

Challenges from other religions. Ado-Ekiti's Muslims face enormous challenges in the educational sector. The effective teaching of Arabic and Islamic studies in public schools is hindered by the non-availability of adequately qualified teachers. Those employed to teach face the problem of conversion into class teachers when they attain higher qualifications, which does not give them the opportunity to effectively teach the subjects to all students in their schools.$^{54}$ This problem is compounded by the inadequate number of Muslim teachers who could represent the interest of Islam in the schools. In addition, 
the number of Muslim principals, vice principals, and headmasters at the primary school level is very low. Most of the Muslim private schools are headed by non-Muslims and assembly devotions are conducted in the Christian way, owing to the lack of Muslim teachers (who are supposed to do it). Muslim parents and imams, both of whom could visit their community schools to help conduct the morning assemblies and oversee the general well-being of Islam and the students, show little or no interest in doing so..$^{55}$

In a recent development, some Muslim teachers have had nasty experiences when they appeared before a screening panel on regularizing the appointment of teachers. For example, those who had a beard were subjected to serious questioning as to why they had one, given that they were public servants, and were also called derogatory names. Similarly, a Muslim staff member of a ministry was denied promotion screening because her hijab was said to be too large, while another applicant who had earlier passed a written examination was denied an oral examination because she wore the hijab. ${ }^{56}$ The matter nearly led to a face-off between the government and the National Council of Muslim Youths, which considered this denied promotion screening exercise an act of discrimination. ${ }^{57}$

\section{Conclusion}

The paper reveals that the actual date of Islam's introduction into Ado-Ekiti is unknown. Like many other parts of Yorubaland, its advent was unannounced and unplanned. The first set of Muslims in the kingdom worshipped privately and secretly for many years. By 1836, Ekiti had its first Muslim ruler at AdoEkiti, King Ali Atewogboye. It also shows that the sociopolitical and economic motivations of the two Muslims kings gave Islam a good foundation in AdoEkiti. It also noted the efforts made by Muslims among the ex-slaves returnees who adopted Islam while in exile, to introduce it to their people in their respective towns and villages in Ado-Ekiti and pass on to them the little knowledge that they had about Islam.

Their efforts were later consolidated by foreign Muslim clerics who visited the area and organized open air $d a^{\prime} w a h$ activities. Although Islam was initially well received in Ekiti, it had to overcome many hurdles to survive. During its early days in Ado-Ekiti, the main challenge was the hostility of traditionalists. As a result, many earlier converts reverted to the traditional religion. The latter problems that confronted the Muslims as a result of political, economic, and western education were analyzed, along with the methods adopted to overcome them. 


\section{Endnotes}

1. P. B. Clark, West Africa and Islam (London: Edward Arnold, 1982), 106.

2. Adam al-Illory, Al-Islam Fi Naijiriyah (Agege, Nigeria: Maktabah al-Thaqafah al-Islamiyyah, 1978), 18.

3. A. R. Doi, Islam in Nigeria (Zaria, Nigeria: Gaskiya Corporation, 1985), 110.

4. I. A. B. Balogun, "The Penetration of Islam to Nigeria," Nigeria Journal of Islam 1, no. 2 (1971): 40. See also S. A. Ayilara, Historical Events in Ekiti West, 1960-1961 (Aramoko-Ekiti, Nigeria: Owodunni Printing, 1967), 9.

5. Clark, West Africa.

6. Ibid.; see also S. A. Agbaje, "Case Study in the History of Awo-Ekiti” (M.L.S. dissertation, University of Ibadan, 1983), 24-25.

7. Samuel Johnson, The History of Yorubas (Thetford, UK: Lowe \& Brydone Printers, Ltd., 1921), 26.

8. J. O. Oguntuase, "The Growth and Survival of Islam in Ekiti North Division of Ondo state of Nigeria" (B.A. long essay, University of Ibadan, 1976), 7.

9. Interview conducted with Alhaja Afsat Akorede, The Iya Adini Idofin Ratibi Mosque Odo-Ado, age 74 years, at no. 16 Idemo, Ado-Ekiti, on November 30 30, 2012.

10. T. G. O. Gbadamosi, The Growth of Islam among the Yoruba, 1841-1908(London: Longman Group, Ltd., 1978), 32-84.

11. Interview conducted with Alhaji Ibrahim Omoyajowo, age 60 years, at no. 66, Agric Road, Odo-Ado, Ado-Ekiti, on November 20, 2012.

12. Interview conducted with Alhaji Jamiu Bello Kewulere, the Chief Imam of AdoEkiti, age 65 years, at no. 14 Ogbontuntun Odo-Ado, Ado Ekiti, on October 20, 2012 .

13. Zumuratul Hujjaj, "A Short Outline of Introduction of Islam in Ondo State Nigeria,” part I (1988), 14. See also I. S. Adewumi, "Islam in Ekiti” (long essay, University of Ibadan, 1973), 9.

14. K. M. Raji, "Da'wah Activities of Shaykh Jamiu Ademuakun Ogunrinde A. K. A. Larubawa and Dandawi in Ado Ekiti, Ekiti State" (M. A dissertation, Department of Arabic and Islamic Studies, University of Ibadan, 2001), 52.

15. S. A. Agbetola, "Islam in Ondo State of Nigeria 1850-1960 AD" (Ph.D. thesis, Department or Arabic and Islamic Studies University of Ibadan, 1987), 14.

16. B. A. Ajibade, "The Role and Contribution of Islamic Organization to the Development of Education in Ado-Ekiti" (B.A. project, Department of History, Ondo-State, University, Ado-Ekiti, 1988), 11-12.

17. M. A. Kareem, "The Growth of Islamic Learning in Ado-Ekiti Local Government Area Council of Ekiti-State" (M.A. dissertation, Department of Religious Studies, University of Ado-Ekiti, 2001), 7.

18. Gbadamosi, "The Growth of Islam among the Yoruba," 4. See also, Y. O. Balogun, "The Advent and Development of Islam in Irepodun/Ifelodun Area Council of Ekiti State, Nigeria: 1840-2000 A.D.” (M.A. Dissertation, University of AdoEkiti, 2004), 17-23. 
19. "Islam in Ado-Ekiti," in Programme of Events of the Opening of Ado-Ekiti Central Mosque (1999): 2-3; see also Ajibade Bakare, "The Advent and Impact of Islam in Ado- Ekiti" (long essay, Adeyemi College of Education, Ondo, 1979).

20. B. A. Agbetola, "19th - 20th Century Situation of Education in Ondo State of Nigeria," Journal of Arabic and Religions, University of Ilorin (1998): 219.

21. Bakare, "Advent and Impact." See also, Ajise Dauda, "Short History and Inception of Islam in Ado-Ekiti" (n.p: n.d): 1-2.

22. S. A. Oluwatoki, "Muslim Organizations in Ekiti Central Local Government Area of Ondo State" (B.A. long essay, Department of Religions, University of Ilorin, 1983), 20-25.

23. Interview conducted with Alfa Jimoh Ibrahim, age 81years, at no.11, Oke-Ido, Ido-Ekiti, on November 21, 2012.

24. Interview conducted with Alhaji Abdul-Kareem Ajisafe Imam Igbole, age 78 years, at no, 1, Irona Road, Ado-Ekiti, on November 11, 2012.

25. Interview conducted with Isaq Ashogbon, age 81years, at no. 71, Ikere Road, Ado-Ekiti, on November 11, 2012.

26. M. A. Kareem, "Problems Militating against Islamic Da'wah in Ekiti State of Nigeria: The Way Out," Journal of National Association for the Study of Religions and Education (March 2007): 14.

27. K. O. Sulaiman, "A Critical Assessment of Da'wah Activities of Shaykh Jamiu Larubawa Dandawi," Fountain Journal of Arabic and Islamic Studies (2007): 30-33.

28. Mason Micheal, "The Nupe Kingdom in the Nineteenth Century A Political" (unpublished Ph.D. thesis, University of Birmingham, 1970), 439.

29. Johnson, History, 83-90.

30. Akintoye, Revolution and Power Politics in Yorubaland: 1840 -1893 (London: Longman Group Limited, 1971), 35. see also S. O. Biobaku, Sources of Yoruba History (London, UK: Oxford University Press, 1973), 34.

31. F. O. Jimoh, "The Emergence of Nawair-ud-Deen Society of Nigeria in IkereEkiti" (long essay, College of Education, Ikere-Ekiti, 1994), 7-9.

32. A. Badmus, "The Development of Arabic and Islamic Studies in Otun-Ekiti and its Environs" (B.A. long essay, University of Ilorin), 13.

33. J. V. Egharevba, A Short History of Benin (Lagos: C. M. S. Bookshop, 1934), 78.

34. R. A. Adeleye, The Overthrow of the Sokoto Caliphate, 1879-1903 (London: Longman Group Ltd., 1981), 135.

35. G. M. Adejumo, "The Influence of Islam in Ede" (M.A. dissertation, University of Ibadan, 1995), 23-25.

36. S. A. Balogun, History of Islam up to 1800. Historical Society of Nigeria, Groundwork of Nigeria History (Heinemann Educational Books, Nigeria Plc, 2001), 220.

37. I. A. Seriki, "The Contributions of Chief Moshood Abiola to Islamic Education in Ogun State of Nigeria," Fountain Journal of Arabic and Islamic Studies 1, no. 1 (2007): 61-74. 
38. Interview conducted with Alhaji Dauda Agbetola, current Chief Imam of Sirajudeen society of Nigeria, Ado-Ekiti, age 69 years, no. 10a Odo-Amun, AdoEkiti, on November 2, 2012.

39. Interview conducted with Alfa Muhammed Raji Alakanse, Chief Giwa Adini of Idofin Ratibi Mosque, age 88 years, at no. 31Agric Road, Odo-Ado, Ado Ekiti, on October 20, 2012.

40. Interview conducted with Alhaji Isa Ibrahim, Imam Idofin Ratibi Mosque, age 85 years, at no .14 Idofin Street, Odo-Ado, Ado-Ekiti, on November 20, 2012.

41. J. O. Oguntuase, "The Growth and Survival of Islam in Ekiti North Division of Ondo-State of Nigeria” (B.A. long essay, Department of Religious Studies, University of Ibadan, 1976), 22-25.

42. I. S. Adewumi, "Islam in Ekiti” (B. A. essay, Department of Religious Studies, University of Ibadan, 1973), 21.

43. W. F. Adigun, "A Study of the Contributions of Selected Muslim Organizations to Islamic Education in Ekiti-State" (M.A thesis, Department of Religious Studies, University of Ibadan, 2008), 32-36.

44. H. O. K. Ogunlayi, "The Influence of Western Education on the Development of Islam in Ekitiland" (B.A long essay, University of Ibadan, 1976), 28-32.

45. A. Ibrahim, "Problem Mitigating against the Teaching of Islamic Religious Studies in Irepodun/Ifelodun Local Government of Ekiti State" (B.Ed. Project, Institute of Education, University of Ado Ekiti, 2000), 1-3.

46. The Ansar-ud-deen Society of Nigeria's Constitution: Rules and Regulations (1990): 1 and Egbe Ansar-ud-Deen in Nigeria Eka.-Ekiti fun Iranti Ayeye Ajodun Ojo Ibi Egbe A.D.S ni Ekiti 1949-1974, 2-5.

47. Welcome Address Delivered by the National Vice-President and Chairman of Ondo and Ekiti Council of Ansar-ud-deen Society of Nigeria and Overseas, Alhaji (Chief) Junaid A.F Ogunlayi, at the 1997 Ramadan Lecture at Fajuyi Hall, Ado-Ekiti on Saturday February 2, 1997, 1-2 and Egbe Ansar-ud-Deen in Nigeria, 2-5.

48. H. O. Balogun, "The Role of Islam in the Social Development of Muslim Community in Ado, Ondo State" (B.A long essay, Department of Religious Studies, University of Jos, 1989), 26-28.

49. Interview conducted with pa Oluwole Ogunbayo, age 87 years, at no. 14 Agric Road, Odo-Ado, Ado Ekiti, on October 21, 2012.

50. P. A. Adebiyi, "The Planting of Christianity in Ekitiland: The Roles of the exSlaves," Olosunta Journal of Social Studies 1, no. 1 (1987): 88-90. College of Education, Ikere-Ekiti,

51. S. A. Ayilara, Historical Events in Ekiti West, 1960-1961 (Aramoko-Ekiti, Nigeria: Owodunni Printing Works, 1967), 9. See also S. A Ayilara "Islam in Ekiti” (B.A. long essay, Department of Religious Studies, University of Ibadan), 29-31.

52. I. A. A. Seriki, "Islam among the Egba and Ijebu Peoples" Ph.D. thesis, University of Ibadan, 1986), 58. 
53. M. A. Kareem, "Advent and Spread of Islam in Ekiti-State, 1840-2000 C.E" (Ph.D. thesis, Department of Religious, University of Ado Ekiti, 2009), 14-20.

54. A. R. Mustapha, "The Position of Islam in Nigeria since Independence in 1960: The Experience in Ekiti-State," Journal of University Scholars in Nigeria (2011): 170-75.

55. I. A. Seriki, "Religion and Democracy: Islamic Perspective" Search Light Journal 2, no. 2 (year): 13-15.

56. A. R. Mustapha, "Arabic Language and Its Relevance to the Practice of Islam: The Experience in Nigeria," Fountain Journal of Arabic and Islamic Studies (2007): 21-25.

57. K. O. Sulaiman, "A Study of Da'wah Activities of Selected Islamic Clerics and Their Contributions to the Development of Islam in Ekitiland 1947-2000 C.E." (Ph.D. thesis, Department of Religions, Lagos State University, 2011), 45-47. 